Volume 5, Issue 1 (2016) 54-78 | Published online, 27 February 2017

The publication of the JEOD is supported by the Autonomous Province of Trento, Italy

\section{AUTHOR}

ANTHONY JENSEN

University of Newcastle, Australia

anthony.jensen@newcastle.edu.au

\title{
The 1980s Worker Co-operative Buyout Experience in Australia. Learning from Praxis
}

\section{ABSTRACT}

This article examines one of the most important experiments in workplace democracy in Australia, a worker buyout programme in the industrial heartland of Greater Western Sydney, which was initiated by the New South Wales Government in the economic downturn of the 1980s recession. Here a government programme facilitated the purchase of moribund businesses by their workforce and management and set in motion an experiment in worker self-management of which Australia had little experience. After initial success and transformation, these worker buyouts disappeared. While worker co-operatives are argued to have considerable potential to restructure capitalist nature of production they are not present in large numbers in many economies arousing debate as to whether it is an entry or exit problem. This research explores the dynamics of three of these worker buyouts using a case study approach to investigate this conundrum. The study deepened our understanding of the role of the state in worker co-operative formation by using a theoretical model explaining the emergence, success and degeneration of the worker owned firm.

\section{KEY-WORDS}

WORKER CO-OPERATIVE, WORKER SELF- MANAGEMENT, ECONOMIC DEMOCRACY AND WORKER PARTICIPATION.

JEL Classification: L6, L2, P13 | DOI: http://dx.doi.org/10.5947/jeod.2016.004

\section{Acknowledgments}

The author wishes to thank Adjunct Professor Ron Callus for his assistance with the research and ongoing critique. Thanks also to Nadia Johanisova, Sidsel Grimsted and Ann Apps for peer reviewing the paper. 


\section{Introduction}

The phenomenon of the worker buyout, which defied the logic of company closure emerged in the 1970s and 1980s when workers across Europe, North America and Australia engaged in the purposeful act of taking over and rescuing thousands of failed companies to preserve their jobs and introduced a new form of industrial relations. This raised a number of important questions and provided the empirical evidence to enable the norms of capitalist relations and the orthodox theory of the firm to be challenged. A legacy of this was the formation of institutionalised worker buyout programs in Italy, Spain, USA, Wales, England and France. The propensity for workers to embark on a worker buyout also continues across the Asia Pacific in India, the Philippines, Korea, Australia and South America. How these keep occurring is the subject of this paper.

Out of these experiences new theory and new practices continue to emerge (Won and Jang, 2015; Kim and Jang, 2015) using democratic models of networked governance, which document a situation where everyone works and everyone manages, jointly advancing internal efficiencies, human freedom and personal evolution. The point of instability of capitalism, the collapse of the conventional firm due to insolvency, offers possibilities for the mutualisation (Won and Jang, 2015) of the failed firm into a worker self-managed firm.

\section{Background}

The emergence of the contemporary worker co-operative movement in Australia had its overt expression in reflecting the worldwide trend to worker buyouts of failing factories and mines. This had been catalysed by both the economic downturn due to the oil crisis and the emergence of worker control movements in the 1970 and 1980s coupled with the need to provide and secure jobs in a recessionary period. It is estimated that there were around 50 organisations that could be described as worker co-operatives in Australia.

Most importantly in a reversal historical tradition in Australia, the state took on an experimental interventionist role to support worker co-operatives and worker buyouts with appropriate institutions. Three Australian state labour governments (New South Wales, Victoria and South Australia) set up pilot worker co-operative programs. These attracted trade union interest, all coming together to provide a very promising and rich institutional support for worker ownership.

The programme had ambitious aspirations of a radical and transformative nature, which aimed to provide the building blocks of an alternative economic democracy to capitalism based on the transfer of investment control from corporate domination to the worker (Jensen, 1988). 


\section{The debate}

These worldwide practical attempts and achievements need to be placed within the theoretical debates over the last 150 years to assess whether democratic worker governed enterprises would be a sustainable proposition to save jobs and reform capitalism. Jensen (2014) summarised the debate under four headings.

- Sceptics

Sceptics from left and right argued that the worker co-operative model was not sustainable within capitalism. The non-dialectical Marx and his followers Lenin and Luxembourg argued that the transformation of capitalism could only be achieved when control of society had been transferred to the producing class not through independent associations of workers. The British Fabians rejected workplace democracy as unworkable in favour of reformist state directed socialism and put their faith in the civil servant (Potter, 1891) in contrast to an over optimistic faith in the workingman. Ward (1958) encapsulated the degeneration thesis in arguing that democratic values were seen as not compatible with the logic of capitalism resulting in rent seeking aspirations, underinvestment and exclusion of new members. The classical economists Alchian and Demsetz (1972) argued that capitalistic firms would prevail over the Labour Managed Firm (LMF) in free market economies due to the opportunism of the free riding member contributing a sub optimal effort. Ostrom (1990) also emphasizes the impossibility of the worker co-operative being viable by stating that "principals will not engage in mutual monitoring and engage in a mutually beneficial strategy resulting in LMF demise" (Jensen, 2013: 297).

Dow and Putterman (1999) addressed the questions raised by Pérotin (1999) as to whether the dearth of worker co-operatives was either entry or exit problems stating that the key inefficiencies of worker co-operatives were difficult to overcome: work incentives, monitoring, workers' lack finance, workers' risk aversion, costly collective choice and an inability to deal with asset specificity (Jensen, 2013). Hansmann (1996) also argued that the costs of collective ownership in collective decision making, controlling managers and risk bearing could be too high for sustainability in a LMF.

\section{- Revisionists}

However, the revisionists challenged these views demonstrating with empirical evidence the long-term success and sustainability of worker co-operative across Spain (Oakeshott, 1973) and Italy (Oakeshott, 1978). Oakeshott (1978) also addressed the issue of professional management by illustrating that the democratic problem that the Webb's observed could be simply corrected by separating the objective requirements of management from the subjective nature of democracy. In the UK Jones (1980) challenged the negative views of the Webb's (Webb and Webb, 1920) finding their data flawed and their conclusions ideological blinkered. Zevi (1982) found that between 1975 and 1978 Italian producer co-operatives 
were more dynamic than capitalist firms in sales and employment growth. Eagan (1990) produced an analysis of the dialectical Marx concluding that Marx opened the door to worker co-operatives when he conditionally approved of the worker co-operative if it subscribed to being part of the labour movement, minimised the hire of non-members and contributed funds to the co-operative sector. We were then able to argue, as does Hodgson (1984) as cited in Eagan (1990: 76) that "there is room for manoeuvre within capitalism" and "there is no inherent reason why such a tension should be unbearable". McCain (1999) argued that workers act to protect their firm specific human capital and deliver a potential Pareto improvement being an alternative to the neo classical firm's engagement with rational game strategy. Pérotin (1999) and Dow (2006) argued that the design problems of the LMF due to the asymmetry between capital and labour could be and were being addressed. Dow (2006) presented proposals for a new view of the LMF by stating that economic theory had taken us far as it could and new disciplines of history and social theory were needed. Borzaga and Tortia (forthcoming) advanced the theory of the co-operative firm-presenting co-operation as a superior co-ordinating mechanism than hierarchical control and market exchanges.

\section{- Contextualists}

Further clarification was provided by the contextualists who argued that the propensity of workers to form worker co-operatives and transform society was related to the cultural norms exhibited by politics of left and right, the variety of capitalism and the orientation of the trade union movement (Poole, 1986b). Spain and Italy were the focus of worker buyouts in the 1970s and 1980s reflecting their syndicalist and anarchist union orientation. Borgaza and Tortia (2006) then argued that contextual influence is a necessary extension of a new theory of the firm, which also addressed Dow's concerns that we go beyond economics and reflect history, industrial relations and comparative political economy.

\section{- Evolutionists}

The institutionalists further clarified our understanding by arguing that the worker owned firm could only be explained though an evolutionary perspective distancing it from the "black box equilibrium seeking model of the neoclassical economists" and arguing that the LMF was either in a state of degeneration or renewal (Jensen, 2013). Life cycle models were developed by Batstone (1983), Lichtenstein (1986) and Ben-Ner (1988) distinguishing startup, early maturity and late maturity. Lichtenstein (1986) also argued for the LMF to be an organisational learning vehicle fostering the "phenomenon of human learning which has to succeed both economically and pedagogically" (Lichtenstein, 1986: 55-56) being both a social and economic success. 


\section{The theoretical model}

These debates enabled a theoretical model to be proposed (Jensen, 2013), using six factors, both macro and micro, drawn from the literature, which explain the emergence, success and failure of the LMF. The model draws on Clarke's (1984) framework and conceptualisation of alternative structures and orientations where there is a tension between commercial viability and democratic control. Clarke (1984) uses the factors of economic structure, organisation and control and work experience to describe the orientation of the LMF but does not take into account how these factors impact on the life cycle model of emergence, success and degeneration.

The theoretical model used here explores the internal and external dynamics of the worker cooperative where it is the management of tensions between "the contradictory demands of market efficiency and the employees wish for democratic management" (Westenholtz, 1986: 149), between economic and social values, namely the forces seeking to integrate the worker co-operative into the market system versus the values seeking to transform the worker co-operative into an alternative organisation (Clarke, 1984). These constitute the essential causal dynamic of eventual sustainability, degeneration or regeneration.

The theoretical model consists of six factors-three macro external and three micro internal which impact on worker co-operative emergence and success. The three macro contextual factors which determine the type and form the worker co-operative takes and its emergence are (i) the state, (ii) the market, and (iii) the labour movement, as the key institutions that effect workers' consciousness and ability to take the initiative and conduct a worker buyout. The three micro factors which describe the internal workings of the worker co-operative and its ability for form an evolving, sustainable high engagement learning organisation are (iv) legal design, (v) governance architecture and (vi) the development of the human resource motivational system creating a learning organisation that is entrepreneurial and has an evolutionary life cycle.

The macro factors impact on the emergence of the LMF as inhibitors or enhancers, either hindering or being conducive to the formation of worker buyouts. Where these macro forces align positively, the result is an exercise of collective power by workers to take control of a situation threatening their jobs and to procure the business. Lansbury and Wailes (2003) describe this alignment as a "favourable conjunctures" theory.

There is however a tension as to the type of worker co-operative that will result from this intervention. Clarke (1984) describes the type of capitalism we are dealing with and the type of firm that will subsequently emerge and the trajectory of its subsequent life cycle offering two alternatives: an incorporatist model—known as worker capitalism—which neatly fits into the liberal market economy or the transformationalist model—known as worker co-operatives-being "part of a struggle for a socialist society" (Clarke; 1984: 101). The tension between the two models has been contrasted by Borzaga and Tortia (forthcoming) who argue that co-operation as a coordinating model with accompanying reciprocity, fairness and trust can be more effective in efficiency than 
the possessive individualism of the principal agent model which suffers from free riding and opportunism. In this paper, we study a hybrid between these two models.

The micro factors have an impact on the success of the firm both socially and economically. The issue of the superior performance of the LMF compared to its capitalist rival is a major a concern by researchers to justify support for the LMF based on performance. Here we can address the question as to whether the constitutional design, the governance, the human resource practices and LMF as a learning organisation can result in a high performance workplace brought about by co-operative ownership or result in degeneration.

The table below illustrates the way these factors are integrated into an explanatory model. Importantly it also illustrates the predictive capacity of the model. By analysing each of the factors, the model can be seen as a template to describe the key influences affecting the worker co-operative formation and evolutionary trajectory. It enables comparison with other studies. However, it also enables predictions to be made as to what kind of worker co-operative will emerge, namely integrative or transformational, and whether the contradictory tensions are bearable or unbearable.

Table 1. The six key factors influencing the emergence and success/failure and type of labour managed firm

\begin{tabular}{lll}
\hline & Worker ownership & Worker co-operation \\
\hline Macro factors & Commercial viability Integrative & Democratic control Transformative \\
$\begin{array}{l}\text { 1. Role of state } \\
\text { 2. Role of trade union }\end{array}$ & Liberal pluralism & Class paradigm \\
3. Role of market & Collective bargaining & Syndicalism \& anarchism \\
\hline Micro factors & Unmediated liberal market economy & Mediated market economy \\
\hline $\begin{array}{l}\text { 4. Legal design } \\
\begin{array}{l}\text { 5. Governance architecture } \\
\text { 6. Human resource management } \\
\text { \& life cycle of the learning } \\
\text { organisation }\end{array}\end{array}$ & Murket efficiency & \\
& Extrinsic satisfaction & Collective \\
\hline
\end{tabular}

Source: Clarke (1984: 101)

This is described as follows:

"In conclusion the theoretical model enables us to predict when a LMF will emerge and what type of LMF results. The model also enables us to predict that the LMF that combines all the features of a democratic control will become successful transformative high performance work system; the firm that combines the integrative features will be commercially successful and degenerate; while the firm that mixes all the features will fail due to unmanageable tension" (Jensen, 2013: 303). 


\section{Managing the tensions}

Tensions are managed ideally through the corporate governance system, which is considered to be the system of rules, practices and processes by which a company is directed and controlled, and in so doing balances the interests of many stakeholders, which includes the control of management in the best interests of the company (Blair and Stout, 1999). However, democratic corporate governance has the potential for conflict between management and members due to role ambiguity and subsequent role confusion in an organisation that is itself in a contradictory class situation due to the different values of its members.

The key to the success of the LMF is not the absence of tension but the management of these tensions. These can be seen from both a pluralist and radical perspective. Sarti (2006) sees management as both "referee and fight promoter" with a role to initiate debates such as in Mondragon where debates are institutionalised between polarised values. Yet, Marglin (1974), from a class paradigm perspective argues in the article What Bosses Do, that the function of management is to control production in such a way as to deliver a larger surplus than if the workers were left to decide the pace of production and rate of accumulation.

This clash of values between management and workers and the impossibility of the Anglo Saxon tradition of worker self-management and the control of management was originally identified and critiqued by the Webb's (1920) who turned the labour movement away from participative democratic governance to collective bargaining and parliamentary reform with their classic analysis:

"The relationship set up between a manager who has to give orders all day to his staff and the members of that staff who, sitting as a committee of management, criticise his action in the evening with the power of dismissing him if he fails to conform to their wishes has been found by experience to be an impossible one" (Webb and Webb, 1920: 154-167).

This clash will be explored in this article with the assumption that the outcome of this struggle will determine whether a worker co-operative or worker corporation emerges. In such a context the "tough governance question is how much power to give to employee directors" (Gordon, 1999: 335) and it is a study of such a decision that forms a central theme of this article. In this context, the role of management becomes paramount in balancing the tension between market efficiency and democracy. The outcome will determine whether the LMF is a transformative or incorporative organisation.

\section{Methodology}

The research on which this article is based was carried out by the author from early 1984, as research for a Master's thesis, and went through to 1988, though the main activity was in 1985 and 1986. This involved participant observation, interviews and the administration of structured 
questionnaires. It coincided with the state governments worker buyout programme achieving a high degree of success and was gaining the attention of politicians of both sides of the political divide. The firms were contacted again in 1996 to ascertain what was the outcome of this experiment in workplace democracy.

\subsection{Case study firms}

All the three case studies were management lead worker buyouts. When management learnt that the business was for sale on the open market they sought an alternative solution and approached the New South Wales Government's pilot programme, the Common Ownership Development Agency $(\mathrm{CODA})^{1}$, which managed Common Ownership Finance (COF) to assist the employee buyout. COF provided "soft loans" to the business, access to an overdraft facility with the bank and assisted in acquiring bank loans of 5,000 AUD to all employees to invest in business. A brief description of the three cases follows:

- "Firm 1 was a printing firm owned by Spotless Dry Cleaning. It was no longer profitable and had become a victim of the process of corporate rationalizing and divesting poorly performing companies. It was put up for sale. There were 14 workers, which grew to 20 following the buyout. It was unionized by the Printing and Kindred Industry Union, which exhibited solidarity as well as an individualistic master craftsmen culture. The firm took over another printing firm and invested in the purchase of a state-of-the-art fourcolor printing press" (Jensen, 2014: 28).

- "Firm 2 was owned by the Adelaide Steamship Company and was a loss-making manufacturer of supermarket refrigeration equipment. There were initially 60 workers, which grew to 70, and it had a strong union-the Amalgamated Workers Unionwhich exhibited a strong collectivist and solidarity culture. It was put on the market and the workers feared for their jobs" (Jensen, 2014: 28).

- Firm 3 was a firm of twenty-two people, an electrical motor repair and service company whereby workers in company vans visited factories to conduct maintenance. It was a privately owned company with the owner retiring and was to be sold as a loss making concern. It was serviced by the highly individualist Electrical Trades Union. Ambitious management embarked on entrepreneurial ventures, which created losses and conflict (Jensen, 1988).

The research on these three case study firms was carried out over a period of four years and began after they had been the subject of a management lead worker buyout and had passed through the start-up "honey moon" phase of enthusiastic camaraderie and primitive participative democracy

Due to worker co-operatives being omitted from the 1923 New South Wales Co-operative Act, it was not possible to register a worker co-operative and the name of the New South Wales Co-operative Development Agency had to be changed to Common Ownership Development Agency, and the finance arm was called Common Ownership Finance $(\mathrm{COF})$. 
and had entered the conflict phase. All members including management had an equal shareholding. The general manager had a seat on the board together with elected members. The businesses had been inefficient, moribund and loss-making before the buyout and two were seen as a liability by their owners.

The research was conducted in the classic "conflict phase" of early maturity, as management, through the unitarist lens, exercised its managerial prerogatives to implement strategies to increase sales, in the face of worker resistance, which can be viewed through their co-operative solidarity lens, and reduce costs to bring about a return to a profitable state. This resulted in a period of intense debate over policy and a class polarisation between blue collar workers in conflict with management, described by Russell, Hochner and Perry (1979: 340) as "an uneasy tension between workplace hierarchy and democratic participation".

Firm 1 and Firm 2 were firms which found that they had discordant cultures only after the buyout - this was reflected by the workers in the survey where 79 per cent of workers believed that there were a number of different groups operating within the organisation and 57 per cent believed that there was a genuine difference in interest between different groups of workers, and finally 70 per cent believed that there was a destructive "them/us" culture in the firm. This article records this deepening debate about values as to how the firms will be run either as commercially pragmatic LMFs or on the other hand transformative organisations managed in special ways and describes the final resolution of this debate and indeed power play from the perspective of a mutualising process described by Won and Jang (2015).

\subsection{Research design}

A case study approach was chosen to study these three firms, using a mixed methodology of participant observation, semi structured interviews, and a structured questionnaire survey administered to workers in the firms. The case study approach was chosen as it enables a broad holistic approach to be taken in order to explore the complex web of internal relations. The method allowed for the cross-referencing of the data as well as allowing a longitudinal study over a number of years in which the dynamics and changes of worker ownership could be observed. The author was a participant observer by working in All Graphics for eighteen months during which time a journal was kept of conversations, meetings and observations. These case studies were chosen as they were geographically accessible, they were all based on the same legal/financial model and they were considered good examples of industrial worker owned firms.

\subsubsection{Semi structured interviews}

Managers of the three co-operatives were interviewed a number of times and the interviews recorded. Group interviews were also conducted with the workers by receiving access in meeting rooms during luncheon periods. Other interviews were conducted with officials in some of the 
relevant trade unions namely the Printing and Kindred Industries Union, and the Australian Metal Workers Union plus the Labour Council of New South Wales as well as the New South Worker Co-operative Programme.

\subsubsection{The survey: structured questionnaire}

Approximately 25 questionnaires were distributed to employees in each of the three companies totalling a potential survey population of 75 employees. Response rates varied between the firms but where generally quite high-48 questionnaires were returned representing 64 per cent of those distributed. The analysis of the surveys was used to triangulate the interview and participant observation data. Due to the small size of the survey, averages were used to analyse the data and the conclusions drawn can be only tentative,

\subsubsection{Participant observation}

The author was an employee of a worker co-operative for three years as well as conducting research as a participant observer. The author also mixed socially with his workmates. The research was conducted through the recording of conversations, meetings and incidents in a diary. Interviews were conducted and focus groups were held.

\section{Results}

In the most radical experiment in worker self-management in Australia's history the interest was how far the CODA firms were able to introduce worker democratic governance known as selfmanagement in the presence of the "market's demand for managerial efficiency" (Westenholtz, 1986: 148). The historical role and great experiment in distributive justice for the Australian worker has been via centralized and institutionalised representative collective bargaining by the Australian Council Trade Unions, in a tariff protected corporatist economy, whereby jobs were preserved and a basic wage was institutionalised. This has been eroded since the 1970 s with the dismantling of tariffs and weakened by the introduction of enterprise level bargaining by the trade unions. In this process the worker has no rights to information, to profits or to decision making. Pixley summed up this conundrum:

"There was no tradition of worker co-operatives in Australia. The co-operative concepts were unknown here and if the N.S.W. programme was to achieve its aim these concepts had to be learnt and translated into practice" (Pixley, 1985: 3).

A radically new governance structure of organisation and democratic control was proposed based on one member one vote exercised at general meetings. The board of directors was elected annually and appoints the managers who are to be responsible to the members through the board. 
A works council was elected by all workers and was to meet monthly with managers to negotiate on working conditions. Quality circles were seen as a participative process on the shop floor. Managerial prerogatives were curtailed by the restriction on the dismissal of employees, which needed to be referred to a general meeting.

\subsection{Management and the mutualising process}

These worker buyouts were management lead. One of the features of governance in a worker co-operative is the control of management, by the members, which CODA described as the subordination of "the rights of capital to the rights of labour" (CODA, 1984: 6). In these case studies democratic governance came up against managerial rationalism and prerogatives as management set about to instil a new work ethic and financial responsibility to deliver a profitable situation. This was described by a manager who espoused this model:

"It's democracy, but not democracy. You cannot expect them to understand certain things, they never will. You have to set the agenda and get minds working. Don't let democracy run riot as management runs the show" (Interview Manager Firm 1).

This tension over the way the worker co-operative was to be managed, namely in a conventional way or a "special way" was highlighted by the contrasting perspectives of a worker director and the manager at Firm 1 over the values underpinning the management of work versus the selfmanagement at work.

The manager stated: "They stay too long at the pub. They let themselves down" (Interview Manager Firm 1). However, the worker director stated: "We are a team. We have been together for a few years and know each other's private lives. We cover each other. We like drinking at lunchtime. If there is no work we stay in the pub. But we won't let it affect production schedules. We are tradesmen and know what we are doing. I don't know of anyone in the printing industry who doesn't like a drink" (Interview Worker Firm1).

Here workers are challenging the strident unitarist ethos of managerialism by endeavouring to manage themselves responsibly in a special way reflecting solidarity, self-determination and selfmanagement and the difference between their values, which symbolise the transformative model, and their values of management espoused by the incorporative model.

It was in the context to establish a genuine community that there was a struggle to implement changes to the firm's culture to bring about a return to profitability. For management this meant laying off the most vocal workers seen by them as troublemakers but in reality were expressing the oppositional labour values of solidarity, equality and putting people first. The justice of the due process method was the subject of bitter debate. Won and Jang aptly describe this process from their research:

"We find mutualisation is fundamental change for not only ownership and governance but also organisational structure and business strategy. By unexpected changes, the organisation was changed to a new form by chaos and conflict" (Won and Jang, 2015: 2). 
This degree, resolution of this tension and final outcome was mediated by the management style. The three worker owned firms had three different style of general manager. At Firm 2 the general manager was deeply embedded in the labour movement. He was a supporter of the Australian Metal Trades Union and insisted the company paid the union dues resulting in 100 per cent membership_-management included. He defined Common Ownership in a Fabian newsletter (Thompson, 1986: n.a.) as:

"An alternative socio-economic strategy based on the transfer of investment control from corporate domination to the worker and the change of economic decision making to democratic controlled management".

And

"This was a bottom up micro economic strategy in which employees can produce co-operatively and they can decide the best way to produce and how much to produce in a democratically planned economy".

However when trading was disrupted by the loss of a major account, due to an incident not of their making, the company had to be restructured which involved taking the opportunity to lay workers off. The company went into a conflict stage as described by the manager before resolution phase:

"Those who came over best were the most difficult to deal with. They are not educated to what's important. The tail wagging the dog. They don't like the executioner, as the company is a society. But we came out lean and mean. We made hard decisions and are now very profitable. They didn't know who was next but had rights of appeal if they were genuine. There were drug pushers - all sorts of riff raf. But I had to consider the survival of the business" (Interview Manager Firm 2).

The CEO at the strongly unionised Firm 2 summed up the struggle of the three mangers to introduce new work practices:

"You need strong management but it is not respected. If you don't take hard decisions you don't get products off the ground. Management must be tough or you let the workers council get away with too much. They are narrow minded and ignorant. One person digs his heels in and gets a band of supporters. Management must be allowed to manage" (Interview Manager Firm 2).

Firm 2 on the other hand was run by an anti-unionist autocratic manager who also went about implementing a unitarist culture in a paternalistic manner. He stated:

"I am an autocrat though I must admit that common ownership has moderated my attitudes. Employee ownership is like bringing up a family you have to scold, discipline and encourage. Unless I went around every morning and got everyone started this place would never get going”(Interview Manager Firm1).

In Firm 3 conversely the manager had a pluralist participative style, which while more in tune with a worker owned company failed to resolve conflict. He described his role as follows:

"There is a need for authority. Human nature won't take responsibility. My job is to develop people more to be responsible for their own actions to enable them to go home with greater satisfaction. My prime 
responsibility is to create the environment for people to extend themselves, show their skills. Your ego can't get in the way. If you think you must make all the decisions you lose" (Interview Manager Firm 3).

And later in the resolution phase a manager described the failure of management to control production and the ability of workers to resist speeding up the labour process in an unionised factory.

"I'm the severest critic of management. We should be making AUD 500,000 instead of 350,000 AUD on a turnover of 6 million AUD. It's because of the bloody mindedness of the workers and the management inertia we inherited. We are much more productive. It was obscene what went on before. Old habits diehard" (Interview Manager Firm 2).

These views of the struggle by the blue-collar workers and management over the labour process reflected Marglin's (1974) argument that the social function of hierarchical work is not technical efficiency but accumulation. Here it can be interpreted that workers were being socialised into a new paradigm of more intensive and stressful work in order to ensure the success of the business in a competitive market that involved financial accountability that they had not previously experienced.

\subsection{Network governance: everyone works and everyone manages}

These statements of management position defined the tension between the governance system, inhabited by the worker members, and management, which it was supposed to control, and hence the type of worker co-operative that would result-transformational or incorporative: Clarke describes this tension in the worker owned firm:

"Contradictions and tensions are central to their existence as hybrid organisations attempting to carve out a place between capitalism and state socialism” (Clarke 1984: 99).

This tension is now explored examining worker influence at different levels of the firm using Westenholtz's (1986) paradigm. This enabled a constructive analysis to be made of how far these firms were able to extend democratic worker self-management to all levels of the firm in a network governance model in the presence of authoritarian hierarchy. Table 2 shows that worker influence, as reflected by a composite of the three firms, was low at the board level where only 12 per cent of all workers believed they had a great deal of influence and 37 per cent believed they had no influence but was high at the shop floor level where 55 per cent believed they had a great deal of influence and only 7.5 per cent believed they had none. This reflected the hierarchical structures of these firms which was not attempted to be changed by the worker buyout and which lead to tension and frustration. 
Table 2. Worker influence at three levels of the firms $(\mathrm{N}=40)$

\begin{tabular}{lccccc} 
& $\begin{array}{c}\text { Great deal } \\
(\mathbf{\% )}\end{array}$ & $\begin{array}{c}\text { Some } \\
\mathbf{( \% )}\end{array}$ & $\begin{array}{c}\text { Very little } \\
\mathbf{( \% )}\end{array}$ & $\begin{array}{c}\text { None } \\
\mathbf{( \% )}\end{array}$ & $\begin{array}{c}\text { Total } \\
\mathbf{( \% )}\end{array}$ \\
\hline Job level & 55.0 & 30.0 & 7.5 & 7.5 & 100.0 \\
Department level & 22.5 & 52.5 & 15.0 & 10.0 & 100.0 \\
Board level & 12.0 & 22.0 & 29.0 & 37.0 & 100.0 \\
\hline
\end{tabular}

7.2.1 Democratic governance at the level of the general assembly

The general assembly of all worker-owners was the sovereign body of the co-operative designed to be the venue to inform worker members of the progress of the business, to debate and share in decision making. Here industrial democracy was a process where there were institutionalised debates on themes such as: efficiency versus participation, homogeneity versus heterogeneity; solidarity and egalitarianism; and authority and power (Greenwood and Santos, 1991).

Due to the economic crisis of the firms it became a venue of conflict to scrutinize and confront management which was pursuing a path of economic rationalism believing managerial prerogatives gave it the final authority for hiring and firing, salaries, the division and allocation of labour, the distribution of surplus and the nature of the product or service.

The frustration with this democratic process was met with hostility by workers as they attempted to "translate voting rights into democratic control" (Robbins, 1982: 11). The frustration was due to deeply held values by 92 per cent of workers who believed that these decisions of major importance should be debated and made collectively. Disputes occurred over company cars, hiring and firing, salaries, the division and allocation of labour, the distribution of surplus, the acquisition of other companies and the nature of the product or service. Workers tried to challenge managerial prerogatives in these areas.

However, the survey illustrated worker disempowerment in that 80 per cent of workers believed that management ran the co-operative while 57 per cent said they were told what to do. This reflects the views of Eccles who summed up the experience at Kirkby Manufacturing in England: "the issues of control and accountability has been at the heart of the problem faced by the co-operative when trying to modify its performance" (Eccles, 1979: 161).

This tension was exhibited at the quarterly general assembly, which became the scene of the playing out of a power struggle between management and workers in which management controlled the flow of information. For example, a manager at Firm 1 stated that not all information was being given to the workers: "We have more fat in the balance sheet but we won't tell them" (Interview Manager Firm 1). At one stage workers considered voting to remove the general manager in Firm 1 and Firm 2, but finally through lack of confidence deferred to the superior skill and expertise of management. 


\subsubsection{Worker self governance and autonomy on the job}

In contrast it was on the shop floor that the experiment in worker self-management demonstrated its greatest positive impacts as workers experienced autonomy and discretion at work. Some 55 per cent of workers surveyed confirmed that they had a great deal of influence at job level and another 30 per cent said they had some influence while 36 per cent of white collar workers and 38.5 per cent of blue collar workers declared that they were satisfied with the amount of control in their job. Workers demonstrated, despite the acrimony, that they could manage themselves and their work and respond to economic imperatives in raising performance. Here their primary goal of job satisfaction was being radically redefined and they were able to demonstrate innovation as well as exert peer pressure on free riding workers to increase performance. One worker at Firm 2 stated that the productivity had gone up 200 per cent and another described how machine time on a process was significantly reduced. At Firm 1 the new attitude of worker owners, exhibiting peer pressure on the free riders, was manifested by the printers demanding that machine down time be reduced by greater efficiency from the plate makers upstairs.

It was on the shop floor that workers found this model of worker participation a success: 61 per cent of Firm 1 workers, 80 per cent of Firm 2 workers, and 63 per cent of Firm 3 workers rated these firms as "a good place to work" and 73 per cent across all firms said job satisfaction had increased. This added evidence to the argument that worker satisfaction and worker autonomy are linked.

\subsection{Indirect democracy}

At the firm level, there were indirect governance mechanisms. Worker-owners elected the board to represent them and the board elected the manager. The three firms also had elected works councils, a foreign institution in Australia of which workers did not have experience.

\subsubsection{The board}

The board of directors was designed to be the key mechanism of representative democracy that had the responsibility of developing company strategy and directing management. Workers elected directors, as a counter to management, who were responsible for the interests of labour on the shop floor as well as the co-operatives profitability. This was a very difficult dual governance role for workers, as this mechanism did not act as an institution for increasing worker power and influence. The result was that workers were unable to get their preferences heard. A worker-director commenting after a board meeting dominated by the general manager stated: "That meeting was long on profits, short on humanity" (Interview Worker Director Firm 1) reflecting the comments of a manager who stated: "It's business first, second and third" (Interview Manager Firm1). This demonstrated again the contradictory tensions within the firm between the "employees wish for democratic management" and "the market's demand for efficient management” (Westenholtz, 1986: 149). 
The lack of influence at board level compared to job level and department level was demonstrated in Table 2 where only 12 per cent of workers felt that they had a great deal of influence at board level and 66 per cent of the workers said that they felt they had very little or no influence at board level.

But managers perceived that workers were not commercially astute enough to act as competent directors and make sound commercial decisions concerning their working class colleagues and employed strategies to circumvent worker power.

Outside consultants were brought in as directors to strengthen board decision making. The continued sense of manipulation of the workers by management was reinforced by the comment of a manager at Firm 1: "John (the consultant to the board) has been invaluable. He has shown me how to get things through (board) meetings" (Interview Manager Firm 1).

Again, there were tensions born out of a manager's paternalistic view that the worker owners needed their direction: "They are a bunch of ordinary guys who have been given the opportunity to own their own business" (Interview Manager Firm 1).

\subsubsection{The works councils}

The elected works council was seen as too powerful in Firm 2 where there was 100 per cent unionism in the strong left wing Australian Metal Workers Union. It was ineffectual with a poorly understood role in Firm 1 with ambivalent unionism while in Firm 3 it was irrelevant reflecting the disinterest in unionisation emerging from the individualist nature of self-directed electricians. With workers failure to assert their perceived rights in the assembly, governance on the shop floor again saw democratic and cultural imperatives in conflict with market demands. The worker attitude survey disclosed that 85 per cent of workers felt that they had high influence at shop floor, with 55 per cent feeling they had a great deal of influence.

This was channelled through the institution of the works council at Firm 2, which had a strong collectivist culture. However, it was poorly understood and developed at the other two firms and tension at Firm 1 was exhibited in individualist opposition to management with go-slow periods as workers demonstrated their partial control over the labour process. Not accustomed to works councils, solidarity through work slowdowns was an important mechanism by which workers in the conflict prone co-operative could oppose management, but this again was broken down by the dismissal and removal of outspoken opponents and management working overtime when workers walked off the job. The management, in this situation, then resorted to social control as they went about "getting rid of the bad apples" and "clearing out the dead wood" (Interview Manager Firm 2).

The survey showed a deep frustration with the democratic process in that 43 per cent of workers wanted to participate more in the decisions that affected their work and the company while only 17 per cent did not want any more participation. These figures portrayed a situation where a managerial elite co-existed with a worker's desire to participate in major decisions and there was a struggle to translate ownership rights into democratic control over management. 
This conflict was a result of a lack of clarity in the process of setting up the co-operative. One manager commented: "It is easy to set up an employee owned company, what is difficult is to get everyone to agree on what they want out of it" (Interview Manager Firm1).

In reality, the workers and managers had differences in the way they perceived job security. Management saw the buyout as the beginning of a struggle to make the firm as profitable as possible, cutting costs, expanding sales and increasing productivity and investment to secure the company's future in a niche market in a very competitive market place. As one manager commented; "The good news is we made 370,000 AUD, the bad news is we could have made 500,000" (Interview Manager Firm 2).

The workers on the other hand saw the buyout as an end in itself where securing ownership also was supposed to secure their jobs. Here the systemic goals of the organisation and personal goals of the worker owners conflicted with the financial goals of management. The priorities of workers were firstly job satisfaction, then job security, profits and finally a say in running their own business. Some believed managers to be "greedy" in their drive for profits. Greenwood and Santos (1991: 147) describe this process of conflict and resolution at Fagor (Mondragon) and how through a process of industrial democracy compromises can be made between "practical possibilities and industrial democratic ideals" where there are "sources of criticism and suggestions for alternative courses of action".

\subsection{Transformation or incorporation}

This experiment in workplace democracy by CODA as a strategy to rescue moribund companies was an economic and social success but politically it raised a number of questions as to whether it offered a "third way", an alternative to the capitalist model or it was a strategy to strengthen the capitalist market system.

While workers were unable to subvert market forces to the democratic aspirations of the worker co-operative they had however worked out an optimal point, a hybrid, between these two contradictory models, which can be seen as both integrating the firm in the market economy but with various degrees of self-direction, reciprocity and fairness.

From an economic aspect, by 1988 the firms arrived at the maturity stage in a sound economic position. In all firms, sales and profits increased significantly. Firm 1 increased its sales from 0.7 to 2.4 million AUD; Firm 2 from 2.8 to 6.2 million AUD; and Firm 3 from 1.8 to 4.1 million AUD. Profits increased at Firm 1 from 66,000 to 120,000 AUD; at Firm 2 from a loss of 60,000 to a profit of 350,000 AUD; and at Firm 3 from a loss of 30,000 to a profit of 150,000 AUD. In accord with this and in line with the incorporative model, share values went up 420\% at Firm 1; at Firm 2 their share capital went from 2,500 to 8,000 AUD; and at Firm 3 their share value went from 1.00 to an expected 15.00 AUD per share.

From the social aspect, jobs had been both saved and created. Firm 1 expanded from 14 to 17 employees, Firm 2 from 60 to 70 and Firm 3 from 29 to 60 and. Importantly 89 per cent of 
workers saw this experiment as a model to improve working life. The firms could be seen to have justified the micro level strategy of CODA in saving jobs, creating new and better jobs in very profitable enterprises, which were carrying out substantial investment programmes at the local level. The companies were more dynamic, winning client acclaim for producing products of outstanding quality at Firm 1 or winning an Australian Design Award for innovation at Firm 3.

From the political perspective by stage three of the life cycle, as Lichtenstein (1986) predicted, the forces of degeneration had set in. The democratic ideal was fading as membership dropped 64 to 35 per cent at Firm 1 and from 75 to 40 per cent at Firm 3, while at Firm 2 solidarity and unionist values prevailed with membership falling only from 100 to 85 per cent. Profits increased the companies' share values, which sometimes tripled increasing the value of the membership package of 5,000 shares to 15,000 AUD. This made it difficult for new members to afford to buy into membership. The firms did not increase the percentage of members but did replace some departing members. All these results made the firms "saleable objects" (Putterman (1988) in Sacchetti and Tortia, 2015: 178). and were an incentive for the workers to sell the business, as a former adviser in the program stated: "to pay off their housing loan and get another job" (Interview Adviser Firm 2).

In the early 1990s, in the absence of a supporting network with the withdrawal of state support for worker co-operatives and with a corporate legal model that guaranteed a market for their individual shares all businesses were sold by their shareholder workers - structured as a shareholder business they behaved like one. In line with the predictive theoretical model the two companies with the coherent culture did well namely Firm 1 (integrative) and Firm 2 (transformative). Firm 3 with a pluralist culture declined.

Firm 1 workers sold the business, as they believed that newer printing machines were marginalising their product offering. Firm 2 workers sold as they failed to raise capital to re tool their refrigeration making plant. Firm 3 ended as a management buyout when a small number of remaining worker owners acquired the company which by this time was reported as being insolvent.

In summary, moribund businesses had been turned into profitable concerns demonstrating the high motivation, innovativeness, strong leadership and engagement that worker ownership brings to the worker co-operative. Worker ownership is not the absence of tension but the management of tension that these managers accomplished under very difficult circumstances, where the values and aspirations of labour and capital collided. The initial success of the CODA programme reflected what Paton (1989) found that worker buyout success depended on strong leadership, a homogenous workforce and ongoing specialist support. The CODA programme saw Firms 1 and 2 demonstrate the first two characteristics, albeit after a struggle, but had the third factor, ongoing support of the state and labour movement in the form of advice, training and access to finance, removed by Government with the closure of CODA's successor the Worker Enterprise Corporation. 


\section{Discussion of Results}

The worker buyouts started with great optimism in stage one of the lifecycle-when the businesses were taken over-exhibiting a belief they could transform its profitability and the nature of work. In stage two after intense debate and tension they emerged as profitable worker owned business, known as worker ownership not worker co-operation (Clarke, 1984). In stage three, demise, the worker owners sold the business and returned them to the private sector in a profitable reconstructed state. We now draw on the six factor theoretical model (Jensen, 2013) to assist us understand the emergence, success and disappearance of these firms in the light of the transformative and integrative tensions which play out and determine the final outcome.

\subsection{Micro factors}

The forces of degeneration emerged at the micro level resulting in an integrative model of worker ownership, which featured individual ownership, representative democracy and extrinsic satisfaction. Leadership was bureaucratic in the context of a culture underpinned by a class paradigm. The contradictory tension between worker aspirations and the managerialism that predominated was epitomised by one manager's comments: "Common ownership is like a business transaction, like a share market. It is not a secure job. If this is the attitude we are dead" (Interview Manager Firm1).

\subsubsection{Human resource processes}

The process of degeneration and integration had its genesis in the tension between conventional management pursuing profit maximisation in the manner of an investor owned firm versus the ideal of the Worker Co-operative programme aspiring for managing the firm in a democratic collectivist way where social relations strive for the ideal of community being effective and holistic in themselves (Rothchild-Witt, 1979). However, this was mediated through conflict into a new hybrid form of organisation where job satisfaction had increased, democratic control was enhanced in the presence of hierarchy and these firms were seen as a good place to work and a way of restructuring employment relations. They were happy workers. The tensions had not become unmanageable.

\subsubsection{Governance}

The objective of the governance architecture was to place managerial control in the hands of the members. The result, which emerged, through conflict however, was a hybrid of representative democracy, shop floor power, works council power sharing in one firm and reduction to a managerial core of owners. There was a sense of frustration with the entrenchment of managerial authority on the one hand and a greater sense of power on the shop floor on the other. There was a desire 
of workers to participate more in the management of the enterprise and their own work. The robustness of the governance system and responsibility of management to meet their fiduciary duties was demonstrated in a representative model.

\subsubsection{Legal structure}

Structured as a company the firms behaved as a company. Unable to use the co-operative structure, the CODA chose to use a company limited by shares with the principles of the International Cooperative Alliance written into the Memorandum and Articles of Association to embed co-operative values and deliver the socially and politically transformative model. However, worker members were not socialised with these co-operative principles. As a result, features of the transformative CODA model - such as the formation of a collectivist indivisible reserve and all assets on liquidation to be passed to the community-were rejected by members.

The rise in the share price was an enticement for the worker members to sell the business to realise a profit on their investment. This is in contrast to the original desires of being "mutual benefit coordination mechanisms" for their members protecting participation rights and long-term stability of employment (Sacchetti and Tortia, 2015: 179).

In summary the tension in the human resource processes between shop floor camaraderie and managerialism persisted but the organisations were seen as a good place to work and a model to transform industry. However, the governance structure disappointed some who had aspired to genuine democracy "employee ownership is oversold" stated one worker (Interview Worker Firm 2). Finally, the legal corporate ownership structure lead to degeneration due to pecuniary motives dominating: "It became a saleable object" (Sacchetti and Tortia, 2015: 178).

\subsection{Macro factors}

At the macro level the firms lacked ongoing support, which was seen as crucial by Paton (1989) for survival of worker democratic experiments. The mediated liberal capitalism of the Australian economy with a trade union movement that was incorporated into bargaining arrangements to set legally determined wage structure and conditions was an unfriendly environment. The withdrawal of the state supported Worker Enterprise Corporation was the final act, which brought the experiment down.

\subsubsection{The Labour Movement}

The labour movement, represented by the trade union movement, was confused by the experiment in workplace democracy and the ambiguous class position of worker owners in a worker buyout. It had no experience of a syndicalist or anarchist tradition. The Printing Industry and Kindred Union 
(PKIU) craft orientated union took the position that they could not represent the workers who were owners not employees. The Amalgamated Metal Workers Union (AMWU) however in an act of solidarity supported the Firm 2 buyout and workers maintained a high membership of the union. It was their solidarity culture, which created a transformative model based on solidarity, frustrating the desires of management to speed up the labour process, maximise profit and break down the culture. Membership of Firm 2 remained at 80 per cent while the Firm 1 fell to 65 per cent and Firm 3 to 45 per cent. The individualist Electrical Trades Union in Firm 3 was ineffective. The unions played no role in attempting to prevent the sale of the businesses as they did with a worker owned steel company in Western Australia or a trade union operated mine in New South Wales.

\subsubsection{The market}

The liberalisation of the Australian market place, globalisation and the rise of neo liberalism in the form of reduced tariff barriers manifested in the policy direction of sacrificing Australia's manufacturing industries in return for trading off foreign imports in return for the export of Australian iron ore and minerals to China. Manufacturing began to move to Asia as Australia transited from a mediated corporatist state to an unmediated liberal market economy. This changed policy direction from saving Australian companies through supply side responses to one of opening up the country to competition in order to make industry more efficient was an unfriendly environment.

\subsubsection{The state}

The historic intervention of the state to support worker buyouts in New South Wales created ideological tensions amongst politicians of both left and right persuasion. CODA had a special worker buyout fund, COF, managed with support of the NSW Co-operative Federation. This was immediately successful in facilitating worker buyouts as Common Ownership Companies with access to "patient capital".

However, the programme was seen as too commercial (integrative) by the left wing Minister responsible who set up enquiry conducted by a trade union consultancy. This recommended, as worker co-operatives were not known in Australia, that they should be based within the trade union movement - a trade unionist needed to be on the board of directors of worker co-operatives- to prevent degeneration. The name was changed to the Worker Enterprise Corporation signifying a move to the transformative Left Labour model. This saw the co-operative as a potential vehicle for state intervention in the economy in association with trade unions. The support for the programme and rate of formation of worker buyouts virtually ceased.

Without support of the labour movement and access to finance the importance of the state acting as an enabler of worker co-operative formation was demonstrated. Despite the manifestation of the "happy worker" and the positive economic and social impact without CODA or W.E.C., only 
two worker co-operative buyouts were formed in the 1990s and the original twenty (approximately) CODA buyouts of the 1980s sold out, degenerated and disappeared-including the three buyouts which are the subject of this study. However politically it is important to give the final word to a worker at Firm 1 who stated, "The most important thing for us was to be in charge of our own destiny" (Interview Worker Firm 1). For a brief moment in time economic democracy was dynamic, real and visible.

\section{Conclusion}

The transforming of moribund manufacturing businesses through the medium of a worker buyout in a mature industrial country such as Australia in the 1980s has enabled a deeper understanding of the factors that make up the characteristics of the success of such a radical venture in workplace democracy. This experiment seems to support the view of the new institutionalist authors that co-operatives are transitional organisations, which will be overcome by "regulation of markets and heightened competitive pressures" (Borzaga and Tortia, forthcoming). These results provide further rich insights into the dynamics of emergence and disappearance.

The research in the 1980s (Jensen, 1988) on three of these worker owned businesses demonstrates that different outcomes result and that such a transformation is complex and problematical. This research demonstrated the usefulness of extending the multifactor theoretical model (Jensen, 2013), which had been developed from research in Spain, Italy and the USA, to explain worker co-operative emergence, behavior and decline in the Australian jurisdiction. While the research was conducted on a very small sample and must be treated with caution, it produced a number of interesting insights and conclusions which could provide useful policy guidelines for transiting companies to worker co-operatives in Australia in areas such as family business succession and corporate rescues due to insolvency.

High performance workplaces can be created from worker buyouts. These firms were transformed into good places to work primarily due to increased discretion for employees over their work and the increase in job satisfaction. Importantly, despite increased tensions and stress, they were seen by their workers as models to transform industry.

A robust governance system is necessary to manage the contradictory tensions in this process of creation of a new worker owned and managed co-operative organization through "conflict and chaos" (Won and Jang, 2015). Essential to this is a functional works council that can act as a counter to management prerogatives.

An inappropriate legal structure will result in degenerative tendencies emerging in the cooperative. Individualist share based schemes are generally inappropriate for the long term survival of a worker owned firm as they can result in the exclusion of new members and escalating share prices inducing a tendency for worker members to sell the firm. 
A supportive organization, whether it is provided by the state or some other institution is essential for the successful start-up and longevity of the worker co-operative. For the emergence of the co-operative and the overcoming of disadvantages such as lack of finance, lack of access to planning skills, risk adverseness of workers, asset specificity and the cost of collective decision making it is necessary to have access to a supporting organization. However, it can only be one factor in determining whether the worker owned firm, which emerges, is transformative or integrative.

Transformative worker buyouts, elevating the interests of labor in relation to capital, can emerge dependent on the nature of the labor movement. One firm was transformative, Firm 2, while Firm 1 was integrative and Firm 3 had mixed orientations, which were not manageable. However, in Firm 2 the socialist orientated Australian Metal Workers Union plus sympathetic labour orientated leadership by the general manager resulted in a transformative organization that exhibited solidarity, equality and fraternal values, which however conflicted with management's financial objectives. Importantly these paradoxes and tensions were manageable.

In conclusion, the transformation of companies to worker co-operatives to regenerate industry in mature economies is a promising area for policy development and state involvement to advance worker self-management, social inclusion, industrial renewal and economic democracy. It is clear that such a process results in tensions due to external and internal contradictions but that these tensions need not be unbearable and it is the management of those tensions that are a determinant of success.

\section{References}

Alchian, A. \& Demsetz, H. (1972). Production, information costs, and economic organization, American Economic Review, 62(5): 777-795.

Batstone, E. (1983). Organization and Orientation: A Life Cycle Model of French Co-operatives, Economic and Industrial Democracy, London Sage, 4:139-161.

Ben-Ner, A. (1988). The life cycle of worker-owned firms in market economies, Journal of Economic Behaviour and Organisation, 10: 287-213. North Holland: Elsevier Science Publishers.

Blair, M.M. \& Stout, L.A. (1999). A Team Production Theory of Corporate Law, Virginia Law Review, 85 (2): 247-328. DOI: https://doi.org/10.2307/1073662

Borzaga, C. \& Tortia, E.C. (2006). An evolutionary perspective in the theory of social enterprises. Paper presented at the IFEPA Conference, Mondragon, Spain.

Borzaga, C. \& Tortia, E.C. (fortchcoming). Co-operation as Co-ordination Mechanism: A New Approach to the Economics of Co-operative Enterprises. In: J. Michie, J. Blasi \& C. Borzaga (Eds.), The Handbook of Co-operative and Mutual Businesses. Oxford: Oxford University Press.

Clarke, T. (1984). Alternative modes of cooperative production, Economic and Industrial Democracy, London: Sage, 5 : 97-129. DOI: https://doi.org/10.1177/0143831X8451006

CODA (1984) Submission to the policy review by the Transnational Co-operative. Common Ownership Development Agency. 
Dow, G.K. (2006). Creative destruction in the theory of the labor managed firm. Keynote address. IAFEP conference. Department of Economics, Simon Fraser University, British Columbia, Canada.

Dow, G. \& Putterman, L. (1999). Why capital (usually) hires labor: An assessment of proposed explanations. In: M. Blair \& M. Roe (Eds.), Employees and corporate governance. Washington, DC: Brookings Institution Press, pp. 17-57.

Eagan, D. (1990). Towards a Marxist theory of labor-managed firms: Breaking the degeneration thesis, Review of Radical Political Economics, 22: 67-86.

Eccles, T. (1979). Control of the Democratised Enterprise: The Case of KMG. In: J. Purcell \& R. Smith (Eds.), The Control of Work. London: The Macmillan Press. DOI: https://doi.org/10.1007/978-1-349-03356-0_7

Gordon, J. (1999). Employee stock ownership in economic transitions: The case of united and the airline industry. In:

M. Blair \& M. Roe (Eds.), Employees and corporate governance. Washington, DC: Brookings Institution Press, pp. 317-354. DOI: https://doi.org/10.2139/ssrn.169028

Greenwood, D. \& Santos, J. (1991). Industrial Democracy as a Process: Participatory Action Research in the Fagor Cooperative Group of Mondragon. Stockholm: The Swedish Centre of Working Life.

Hansmann, H. (1996). The ownership of enterprise. London: The Belknap Press.

Hodgson, G. (1984). The democratic economy. Harmondsworth, UK: Penguin.

Jensen, A. (1988). Irrational Materialism: The Worker Co-operative Alternative in New South Wales. Master's Thesis. University of Sydney, Australia.

Jensen, A. (2013). The Labor Managed Firm - A Theoretical Model Explaining Emergence and Behaviour. In: D. Kruse (Ed.), Sharing Ownership, Profits, and Decision-making in the 21st Century (Advances in the Economic Analysis of Participatory and Labor Managed Firms), 14: 295-325. DOI: 10.1108/S0885-3339(2013)0000014020

Jensen, A. (2014). Worker co-operatives: Propelling Inclusive growth in Italy, UK and Philippines. In: V. Ramirez (Ed.), Social Enterprise Work that Uplifts Human Life. University of Asia and the Pacific.

Jones, D.C. (1980). Producer cooperatives in industrialized western economies, British Journal of Industrial Relations, 18(2): 141-154. London: Blakewell. DOI: https://doi.org/10.1111/j.1467-8543.1980.tb00840.x

Kim, H. \& Jang, S. (2015). A Worker-Owned Firm's Organizational Change from the Perspective of Organizational Learning: The case of Woojin Traffic. Paper presented at the ICA-ILO International Research Conference "Cooperatives and the World of Work", 10-11 November 2015, Antalya, Turkey.

Lansbury, R.D. \& Wailes, N. (2003). The meaning of industrial democracy in an era of neo- liberalism. In: P. Gollan \& G. Patmore (Eds.), Labor essays. Partnership at work: The challenge of employee democracy. Annandale: Pluto Press. Lichtenstein, P.M. (1986). The concept of the firm in the economic theory of 'alternative' organizations: Appraisal and reformulation. In: S. Jansson \& A.-B. Hellmark (Eds.), Labor-owned firms and workers' cooperatives. UK: Gower Publishing Company Limited, pp. 51-72.

Marglin, S.A. (1974). What do Bosses do? The origins and functions of hierarchy, Review of Radical Political Economy, 6 (2): 60-112. DOI: https://doi.org/10.1177/048661347400600206

McCain, R. (1999). The mystery of worker buyouts of bankrupt firms: An explanation in terms of learning by doing and specific human capital, Economic Analysis: Journal of Enterprise and Participation, 2(3): 165-177.

Oakeshott, R. (1973). Mondragon: Spain's oasis of democracy. In: J. Vanek (Ed.), Self-management, Economic Liberation of Man. London: Penguin.

Oakeshott, R. (1978). The case for workers' coops. London: Routledge \& Kegan Paul.

Ostrom, E. (1990). Governing the commons. Cambridge: Cambridge University Press. DOI: https://doi.org/10.1017/ cbo9780511807763

Paton, R. (1989). Reluctant entrepreneurs. Milton Keynes, UK: Open University Press.

Pérotin, V. (1999). Why there are not more labor-managed firms. Paper presented at the Yaraslov Vanek Memorial Conference. New York, NY, Columbia University. 
Pixley, J. (1985). Worker co-operatives in Australia Today: A case of radical ideas and conservative Policies? Paper presented to the SAANZ Conference, Brisbane.

Poole, M. (1986b). Industrial relations: Origins and patterns of national diversity. London: Routledge \& Kegan Paul.

Potter, B. (1891). The Co-operative Movement in Great Britain. London: George Allen and Unwin.

Putterman, L. (1988). The Firm as an Association versus the Firm as a Commodity. Efficiency, Rights and Ownership, Economics and Philosophy, 4(2): 243-266.

Robbins, J.R. (1982). The Co-operative Alternative: The Revival of a Democratic Ideal in Industry, The Journal of Industrial Relations, 35(4): 647-648.

Rothchild-Whitt, J. (1979). The collectivist organization: An alternative to rational bureaucratic models, American Sociological Review, 44: 509-527. DOI: https://doi.org/10.2307/2094585

Russell, R., Hochner, A. \& Perry, S. (1979). Participation, Influence and Worker-Ownership, Industrial Relations, 18(3): 330-334. DOI: https://doi.org/10.1111/j.1468-232X.1997.tb00932.x

Sacchetti, S. \& Tortia, E.C. (2015). The Silver Lining of Co-operation: self-defined rules, common resources, motivations and incentives in co-operative firms. In: A. Jensen, G. Patmore and E.C. Tortia (Eds.), Cooperative Enterprises in Australia and Italy - Comparative Analysis and Theoretical insights. Firenze, Italy: Firenze University Press, pp. 175-190.

Sarti, D. (2006). Managing dualities in cooperatives: Some evidences from the Italian retail sector. International Association for Employee Financial Participation Conference, Mondragon.

Thompson, F. (1986). Towards the New Economy - Common Ownership, Fabian Newsletter, Vol. 23(4).

Ward, B.N. (1958). The firm in Illyria: Market syndicalism, American Economic Review, 48: 566-689.

Webb, S. \& Webb, B. (1920). Industrial democracy. London: Longmans Green and Co.

Westenholtz, A. (1986). Democratic management and efficiency. In: S. Jansson \& A.-B. Hellmark (Eds.), Labor-owned firms and workers' cooperatives, pp. 140-154.

Won, J.H. \& S. Jang (2015). Becoming a Co-operative with Self-organisation Process: The case of Happy Bridge Cooperative. Paper presented at the ICA-ILO International Research Conference, Cooperatives and the World of Work, Antalya, Turkey, 10-11 November 2015.

Zevi, A. (1982). The Performance of Italian Producer Co-operatives. In: D.C. Jones \& J. Svejnar (Eds.), Participatory and Self-Managed Firms. Toronto, CA: Lexington Books, M.A.D.C Heath and Co. 